\title{
THE IMPACT OF FDI INFLOW ON EX-YUGOSLAV COUNTRIES' LABOUR MARKETS
}

\section{Milica Perić*}

PhD candidate

Singidunum University,

Belgrade, Serbia

\begin{abstract}
:
This paper models and discusses the effects of FDI inflow on the employment rate and average net wages in ex-Yugoslav countries. The sample of countries is chosen due to of the high legacy with FDI, both in transitional (Bosnia and Herzegovina, Macedonia, Montenegro and Serbia) and recently developed (Croatia and Slovenia) economies. This paper argues that FDI inflow should have positive effects on the employment rate and on average net wages in the countries examined. Performing linear mixed-effects models on 78 observations in the period 2003-2017, the empirical results indicate that FDI inflow has positive and significant effects on the employment rate and on average net wages, after 2 years and after 3 years, respectively.
\end{abstract}

Keywords:

average net wage, employment rate, ex-Yugoslavia, linear mixed models, random effects.

\section{INTRODUCTION}

Foreign Direct Investments (FDI) have grown rapidly worldwide during the last few decades, although in 2017 the global flow of FDI in developing countries decreased (UNCTAD, 2018). Not only is FDI inflow labelled as the key factor in global economic development, growth and integration (Bitzenis \& Marangos, 2007), but it has also been adopted as a key strategy for the development of transitional economies (Dabla-Norris, Honda, Lahreche \& Verdier, 2010).

The economic recovery and progress of ex-Yugoslav countries have been supported by different international institutions. Since the crash of the socialist and communist regimes in Yugoslavia, the emerging democracies have been quickly engaged in many aspects of globalization. FDI inflow is suitable for fighting the national economic dysfunction and recession after the recent wars and, according to Chandler (2007), after the Dayton agreement and migrations as well. Figure 1 presents trends in FDI inflow in the countries under examination. 
Figure 1 - FDI inflow in ex-Yugoslav countries: 2005-2017

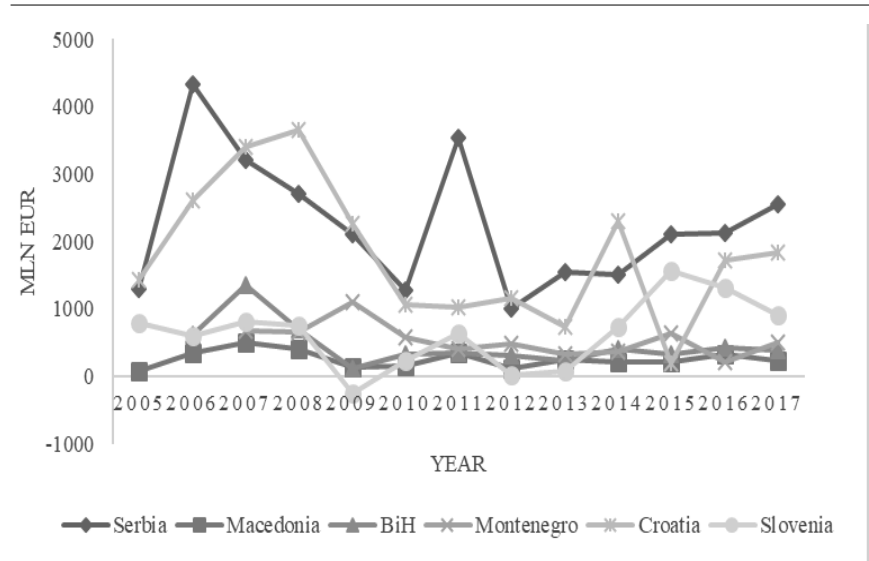

Even as one of the key factors of globalization, FDI inflow creates employment and wage discrepancies (see part 2). In relation to this statement, the object of this research is to measure the effects of FDI inflow on labour market principal indicators. To the best of the author's knowledge, the relationships between FDI inflow and the employment rate, and FDI inflow and average net wages in the countries of ex-Yugoslavia have not been tested yet, and this research is about to cover this gap in the literature. The other reason for selecting this sample of countries is because of its high legacy with FDI (Hadžić \& Pavlović, 2011).

The aim of this paper is to measure the impact of percentage point changes in FDI inflow on percentage point changes in the employment rate and on percentage point changes in average net wages in ex-Yugoslav countries in the period 2003-2017. The expected overall results are the positive and significant effects of FDI inflow on both the employment rate and average net wages.

The structure of this paper is as follows. The second part presents the empirical evidence of the impact of FDI on the labour market. The third part presents the data and econometric models applied. The fourth section shows the estimation of the results and their interpretation, followed by discussion and conclusions as the last section of the paper.

\section{LITERATURE REVIEW}

Table 1 represents a summary of nine empirical studies of the impact of FDI on the labour market. There are seven additional studies of the effect of FDI inflow on wage inequality, which are chosen as representative studies for the approaches used and the results found.

Table 1 - Impact of FDI on labour market indicators - empirical studies

\begin{tabular}{|c|c|c|c|}
\hline Author & Methodology & $\begin{array}{l}\text { The effect of interest and geo- } \\
\text { graphical scope }\end{array}$ & Results \\
\hline Gopinath \& Chen (2003) & OLS regression & $\begin{array}{l}\text { Impact of FDI inward on wag- } \\
\text { es in } 26 \text { countries }\end{array}$ & $\begin{array}{l}\text { FDI inward was found to have } \\
\text { negative effect on wage in- } \\
\text { equality }\end{array}$ \\
\hline Taylor \& Driffield (2005) & $\begin{array}{l}\text { Fixed-effects and GMM esti- } \\
\text { mators }\end{array}$ & $\begin{array}{l}\text { Impact of FDI inward on man- } \\
\text { ufacturing industries shifts in } \\
\text { demand towards higher skilled } \\
\text { labour in UK }\end{array}$ & $\begin{array}{c}\text { FDI inward was found to have } \\
\text { negative effect on wage in- } \\
\text { equality }\end{array}$ \\
\hline Figini \& Gorg (2006) & $\begin{array}{l}\text { Fixed-effects and GMM esti- } \\
\text { mators }\end{array}$ & $\begin{array}{l}\text { Impact of FDI inward on wage } \\
\text { inequality in } 103 \text { countries }\end{array}$ & $\begin{array}{l}\text { FDI inward was found to have } \\
\text { negative effect on wage in- } \\
\text { equality in developing coun- } \\
\text { tries, and positive effect in de- } \\
\text { veloped countries }\end{array}$ \\
\hline Bhandari (2007) & OLS regression & $\begin{array}{c}\text { Impact of FDI on wage in- } \\
\text { equality in transitional coun- } \\
\text { tries }\end{array}$ & $\begin{array}{l}\text { FDI was found to have posi- } \\
\text { tive effect on average wages, } \\
\text { and negative effect on wage } \\
\text { inequality }\end{array}$ \\
\hline Pajovic (2007) & $\begin{array}{c}\text { Case study: analytical ap- } \\
\text { proach }\end{array}$ & $\begin{array}{l}\text { Impact of Renault in Slovenia } \\
\text { and the Slovenian government } \\
\text { on the local economy }\end{array}$ & $\begin{array}{c}\text { Positive spillover effects are: } \\
\text { worker training, indirect job } \\
\text { creation }\end{array}$ \\
\hline Stanisic (2008) & Correlation analysis & $\begin{array}{l}\text { Impact of FDI on economic } \\
\text { growth in South European } \\
\text { transition countries }\end{array}$ & $\begin{array}{l}\text { FDI was found to have posi- } \\
\text { tive effect on employment }\end{array}$ \\
\hline $\begin{array}{c}\text { Driffield, Girma, Henry, \& } \\
\text { Taylor (2010) }\end{array}$ & GMM estimators & $\begin{array}{c}\text { Impact of FDI inward on wage } \\
\text { inequality in UK }\end{array}$ & $\begin{array}{l}\text { FDI inward nationally tends to } \\
\text { increase wage inequality, while } \\
\text { the local FDI inward tends to } \\
\text { decrease wage inequality }\end{array}$ \\
\hline
\end{tabular}




\begin{tabular}{|c|c|c|c|}
\hline Halmos (2011) & OLS regression & $\begin{array}{l}\text { Impact of FDI inward on wage } \\
\text { inequality in CEE }\end{array}$ & $\begin{array}{l}\text { FDI inward was found to have } \\
\text { negative effect on wage in- } \\
\text { equality }\end{array}$ \\
\hline Sabic et al. (2012) & Correlation analysis & $\begin{array}{l}\text { Impact of FDI inflow on un- } \\
\text { employment in Serbia }\end{array}$ & $\begin{array}{l}\text { FDI inflow was found to have } \\
\text { no significant effect on unem- } \\
\text { ployment }\end{array}$ \\
\hline Zulfiu (2014) & Simulation analysis & $\begin{array}{c}\text { Impact of FDI inflow on wage } \\
\text { inequality in transition coun- } \\
\text { tries }\end{array}$ & $\begin{array}{l}\text { FDI inflow was found to have } \\
\text { positive effect on domestic } \\
\text { skilled wages, and negative ef- } \\
\text { fect on unskilled wages }\end{array}$ \\
\hline $\begin{array}{l}\text { Kurtovic, Talovic, \& Dacic } \\
\text { (2015) }\end{array}$ & OLS regression & $\begin{array}{l}\text { Impact of FDI inflow on aver- } \\
\text { age net wages in Bosnia and } \\
\text { Herzegovina, Montenegro, } \\
\text { Macedonia and Serbia. }\end{array}$ & $\begin{array}{c}\text { FDI inflow was found to have } \\
\text { positive effect on net average } \\
\text { wages }\end{array}$ \\
\hline Jude \& Silaghi (2016) & $\begin{array}{l}\text { Fixed-effects and GMM esti- } \\
\text { mators }\end{array}$ & $\begin{array}{c}\text { Impact of FDI on employment } \\
\text { in CEE }\end{array}$ & $\begin{array}{l}\text { FDI was found to have short- } \\
\text { term negative effect and long- } \\
\text { term positive effect on em- } \\
\text { ployment }\end{array}$ \\
\hline Peric (2016) & $\begin{array}{c}\text { Case study: analytical ap- } \\
\text { proach }\end{array}$ & $\begin{array}{c}\text { Impact of FDI inflow on wage } \\
\text { inequality in Brazil }\end{array}$ & $\begin{array}{c}\text { FDI inward was found to have } \\
\text { negative effects on wage in- } \\
\text { equality }\end{array}$ \\
\hline $\begin{array}{c}\text { Zdravkovic \& Martinovic } \\
(2016)\end{array}$ & OLS regression & $\begin{array}{l}\text { Impact of FDI on unemploy- } \\
\text { ment in transition countries }\end{array}$ & $\begin{array}{l}\text { FDI was found to have no sig- } \\
\text { nificant effect on unemploy- } \\
\text { ment }\end{array}$ \\
\hline Grahovac \& Softic (2017) & OLS regression & $\begin{array}{l}\text { Impact of FDI inflow on un- } \\
\text { employment rate in the West } \\
\text { Balkan countries }\end{array}$ & $\begin{array}{l}\text { FDI inflow was found to have } \\
\text { no significant effect on unem- } \\
\text { ployment }\end{array}$ \\
\hline Peric (2019) & OLS regression & $\begin{array}{l}\text { Impact of FDI inflow on em- } \\
\text { ployment and on average wag- } \\
\text { es in Serbia }\end{array}$ & $\begin{array}{l}\text { FDI inflow was found to have } \\
\text { no significant effect on in- } \\
\text { crease in employment or aver- } \\
\text { age wages }\end{array}$ \\
\hline
\end{tabular}

Source: Author's preparation

Authors argue about the positive or negative impact of FDI on the indicators of the labour market. Whilst Sabic et al. (2012), Zdravković \& Martinović (2016), Grahovac \& Softić (2017), and Perić (2019) stress that there is no significant impact of FDI inflow on employment, Stanišić (2008), Jude \& Silaghi (2016), and Pajović (2007) claim that FDI inflow has a positive impact on employment growth. As far as average wages are concerned, Bhandari (2007) and Kurtović, Talović \& Dacić (2015) claim that there is an increase due to FDI inflow. In relation to predictions, the Variance Decomposition Test developed by Kurtović et al. (2015) showed that over the next 10 years the growth of average net wages will lead to increased FDI inflow, but that the increase in FDI inflow will not have a significant effect on average net wages.

This section shows that FDI has a slight positive effect on the employment rate and on average net wages in transitional countries. However, FDI inflow tends to increase wage inequality, as reported by Gopinath \& Chen (2003), Taylor \& Driffield (2005), Figini \& Gorg (2006), Driffield et al. (2010), Halmos (2011), Zulfiu (2014), and Peric (2016). The results from the empirical literature appear homogeneous: companies under foreign ownership pay higher wages and require a skilled labour force.

On the basis of the results presented in Table 1, the overall impact of FDI inflow on ex-Yugoslav countries remained unknown despite previous research. This study will informal in the literature and contribute to the knowledge about the impact of FDI inflow in the countries under examination.

The following section presents the data used for modelling, the econometric methodology and empirical results. The model specification convention is based on Anderson (2013) and Heck, Thomas \& Tabata (2014).

\section{DATA AND MODEL SPECIFICATION}

This section presents the quantitative variables, a description of the data used for the analysis (3.1), and the specification of the chosen statistical models and the statement of the hypotheses (3.2). 
- Labour market section, retrieved from the official site of each country's statistical office for both the employment rate and average net wages.

Table 2 presents the descriptive statistics for each factor of each country, produced in SPSS software based on 78 observations. data was derived from secondary sources. Thus, the pane data for the period 2003-2017 is constructed with the information obtained from:

- Balance of payments, retrieved from the official site of each country's national bank in the statistical database for FDI inflow, and

Table 2 - Desctiptive statistics

\begin{tabular}{|c|c|c|c|c|c|c|c|c|}
\hline \multicolumn{9}{|c|}{ Descriptive Statistics } \\
\hline & $\mathrm{N}$ & Range & Minimum & Maximum & & & $\begin{array}{l}\text { Std. Devia- } \\
\text { tion }\end{array}$ & Variance \\
\hline & Statistic & Statistic & Statistic & Statistic & Statistic & Std. Error & Statistic & Statistic \\
\hline Year & 78 & 14 & 2003 & 2017 & 2010.94 & .439 & 3.876 & 15.022 \\
\hline IFDI & 78 & 4577 & -253 & 4323 & 1011.37 & 110.583 & 976.643 & 953831.152 \\
\hline$\Delta$ IFDI & 73 & 11.37 & -1.91 & 9.45 & .4539 & .19529 & 1.66858 & 2.784 \\
\hline$\Delta$ IFDI_lag1 & 66 & 11.37 & -1.91 & 9.45 & .4621 & .21391 & 1.73783 & 3.020 \\
\hline$\Delta$ IFDI_lag2 & 60 & 11.37 & -1.91 & 9.45 & .3739 & .19633 & 1.52076 & 2.313 \\
\hline$\Delta$ IFDI_lag3 & 54 & 11.37 & -1.91 & 9.45 & .3939 & .21615 & 1.58835 & 2.523 \\
\hline EMPL & 78 & 37.60 & 24.50 & 62.10 & 43.2242 & .99280 & 8.76819 & 76.881 \\
\hline$\triangle \mathrm{EMPL}$ & 72 & 1.26 & -.42 & .84 & .0162 & .01384 & .11744 & .014 \\
\hline ANW & 78 & 856 & 206 & 1062 & 535.05 & 26.545 & 234.442 & 54963.249 \\
\hline$\triangle \mathrm{ANW}$ & 72 & .49 & -.16 & .34 & .0425 & .00836 & .07091 & .005 \\
\hline dev_st & 78 & 1 & 0 & 1 & .37 & .055 & .486 & .237 \\
\hline $\begin{array}{l}\text { Valid N (list- } \\
\text { wise) }\end{array}$ & 54 & & & & & & & \\
\hline
\end{tabular}

Source: Author's calculation

where:

IFDI - Foreign Direct Investment Inflow in million EUR, $\triangle$ IFDI - Foreign Direct Investment Inflow change rate, $\Delta$ IFDI_lag1 - Foreign Direct Investment Inflow change rate after 1 year,

$\Delta$ IFDI_lag2 - Foreign Direct Investment Inflow change rate after 2 years,

$\Delta$ IFDI_lag3 - Foreign Direct Investment Inflow change rate after 3 years,

EMPL - Employment rate,

$\triangle \mathrm{EMPL}$ - Employment rate change rate,

ANW - Average Net Wages in EUR,

$\triangle \mathrm{ANW}$ - Average Net Wages change rate,

DEV_ST - Developmental stage (economies in transition or developed economies, according to the United Nation's World Economic Situation and Prospects (UN, 2018) country classification).

The above-listed abbreviations for the variables are used in the next subpart.

\section{MODEL SPECIFICATION}

Linear mixed-effects models (LMM) are used to estimate the overall impact of the changes in IFDI and DEV ST on the changes in the employment rate ( $\triangle \mathrm{EMPL}$ ) and on the changes in average net wages $(\triangle \mathrm{ANW})$ in the exYugoslav countries in the period from 2003 to 2017. The changes in variables are measured in percentage points. The lagged terms are used because of the theoretical assumption that IFDI requires time to show the real effects of performing in the country. A typical assumption here is that the regression coefficients have normal distributions, as well as unstandardized coefficients, which means that the coefficients are in their original metrics. The information criterion used to search for the best model fit is Akaike's Information Criterion (AIC). The Maximum Likelihood (ML) method is adopted because it allows inferences to be made on the covariance parameters of the model. The Hausman test is used to evaluate the consistency of the random effects in comparison with the fixed effects.

The author's intention is to determine whether there is a quantitative relation between the dependent and independent variables, based on the following two models: 
$\Delta$ EMPLti $=\gamma 00+\gamma 10 \Delta$ IFDIt $+\gamma 20 \Delta$ IFDI_lag1t $+\gamma 30 \Delta$ IFDI_lag2t $+\gamma 40 \Delta$ IFDI_lag $3 t+\gamma 50 D E V \_S T t+\mu 1 i \Delta$ IFDIti $+\mu 2 \mathrm{i} \Delta$ IFDI_lag $1 \mathrm{ti}+\mu 3 \mathrm{i} \Delta$ IFDI_lag2ti $+\mu 4 \mathrm{i} \Delta$ IFDI_lag3ti $+\mu 0 \mathrm{i}+\mathrm{eti}$

$\Delta$ ANWti $=\gamma 00+\gamma 10 \Delta$ IFDIt $+\gamma 20 \Delta$ IFDI_lag $1 \mathrm{t}+\gamma 30 \Delta$ IFDI_lag $2 \mathrm{t}+\gamma 40 \Delta$ IFDI_lag3t $+\gamma 50 D E V \_S T t+\mu 1 \mathrm{i} \Delta$ IFDIti $+\mu 2 \mathrm{i} \Delta$ IFDI_lag1 $1 \mathrm{i}+\mu 3 \mathrm{i} \Delta$ IFDI_lag2ti $+\mu 4 \mathrm{i} \Delta$ IFDI_lag3ti $+\mu 0 \mathrm{i}+\varepsilon \mathrm{ti}$

where:

$\gamma 00$ - grand intercept capturing the variation amongst

$\mathrm{t}$ in $\mathrm{i}$,

$\gamma \mathrm{n} 0$ - fixed effects across groups,

$\mu 0 \mathrm{i}$ - between-country variation in intercepts - devia-

tion from the average intercept,

$\mu \mathrm{ni}$ - random effects capturing variation in individual

slope coefficients,

$\varepsilon_{\mathrm{ti}}$ - individual-level residual in $\mathrm{t}$ within $\mathrm{i}$.

The model estimations are expressed in the annual growth rate. The dependent variable is: $\triangle \mathrm{EMPL}$ in model (1), and $\triangle \mathrm{ANW}$ in model (2). The independent variables are: $\Delta$ IFDI with its time lags $(\Delta$ IFDI_lag1, $\Delta$ IFDI_lag2, $\triangle$ IFDI_lag3) and DEV_ST for the six countries.

The hypothesis $\mathrm{HO}$ is that changes in both $\triangle \mathrm{EMPL}$ and $\triangle \mathrm{ANW}$ are not influenced by changes in $\triangle \mathrm{IFDI}$ and its time lags and DEV_ST, while hypothesis $\mathrm{H} 1$ is that changes in both $\triangle \mathrm{EMPL}$ and $\triangle \mathrm{ANW}$ are influenced by changes in $\triangle$ IFDI and its time lags and DEV_ST.

In the next section, model 1 is shown as (1), and model 2 as (2).

\section{EMPIRICAL RESULTS}

The estimation is by LMM, or between-groups and within-group estimation. Random effects, therefore, consider idiosyncratic qualifications of the units as non-observable and randomly distributed.
The purpose of the models is to estimate the overall impact of the changes in $\triangle$ IFDI on $\triangle E M P L$ in (1) and on $\triangle \mathrm{ANW}$ in (2). For both models, the dependent variable changes in time $t$ by a certain number of percentage points (not the percent rate), after taking into consideration the level of the changes in $\triangle$ IFDI and DEV_ST of the country in that and previous periods. The outcomes of the Hausman test confirm that the use of random effects is justified, i.e., that the random effects are consistent with the fixed effects.

(1) Results of the Hausman test for ( $\triangle \mathrm{EMPLti})$ : chisq $=0.3577, \mathrm{df}=5$, $\mathrm{p}$-value $=0.9964$;

(2) Results of the Hausman test for $(\triangle \mathrm{ANWti})$ : chisq $=3.0261, \mathrm{df}=5, \mathrm{p}$-value $=0.696$.

Next, assuring the smallest possible value of AIC followed by the theoretical and analytical logic, the models are accepted and presented in Tables 3 and 4.

(1) Akaike's Information Criterion (AIC): -144.462 ;

(2) Akaike's Information Criterion (AIC): -214.973 .

Table 3 - Modelling of employment percentage rate changes

\begin{tabular}{|c|c|c|c|c|c|c|c|}
\hline \multicolumn{8}{|c|}{ Estimates of Fixed Effectsa } \\
\hline & & & & & & \multicolumn{2}{|c|}{ 95\% Confidence Interval } \\
\hline Parameter & Estimate & Std. Error & $\mathrm{df}$ & $\mathrm{t}$ & Sig. & Lower Boun & Upper Bound \\
\hline Intercept & -.005357 & .001773 & 21.279 & -3.021 & .006 & -.009041 & -.001672 \\
\hline$\left[\mathrm{dev} \_s t=0\right]$ & .021609 & .001925 & 14.786 & 11.225 & .000 & .017501 & .025718 \\
\hline$\left[\mathrm{dev} \_s t=1\right]$ & $0 \mathrm{~b}$ & 0 & & & & & \\
\hline$\Delta \mathrm{IFDI}$ & .000867 & .003700 & 19.766 & .234 & .817 & -.006856 & .008591 \\
\hline$\Delta$ IFDI_lag1 & -.001613 & .001916 & 24.429 & -.842 & .408 & -.005563 & .002337 \\
\hline$\Delta$ IFDI_lag2 & .015300 & .005566 & 5.986 & 2.749 & .033 & .001673 & .028927 \\
\hline$\Delta$ IFDI_lag3 & .025344 & .005284 & 7.004 & 4.796 & .002 & .012850 & .037838 \\
\hline
\end{tabular}

a. Dependent Variable: $\triangle \mathrm{EMPL}$.

b. This parameter is set to zero because it is redundant.

Source: Author's calculation 
Table 3 shows $0.015 \%$ and $0.025 \%$ increases in $\triangle \mathrm{EMPL}$ for each additional unit of change in $\triangle$ IFDI after two $(\Delta$ IFDI_lag2) and after three ( $\Delta$ IFDI_lag3) years of its performance, respectively, these are statistically significant for both developed and transitional countries. The strongest positive effect is represented by the $\Delta$ IFDI_ lag3, so for the double increase in IFDI in time $t$ there would be a $0.025 \%(\mathrm{p}=.002)$ increase in $\triangle \mathrm{EMPL}$ after 3 years of foreign investment performance in the country i. The model suggests that the DEV_ST has positive effects on the growth in $\triangle \mathrm{EMPL}$ in transitional countries and it is statistically significant. The greater the foreign investment, the faster the growth in EMPL in transitional countries compared with developed countries, which is in accordance with the theoretical and empirical assumptions that in developed countries there is a lower increase in employment (because of the saturated labour market), while in transitional and developing countries there is more room for faster employment growth (because of the unsaturated labour market). As for model (1), each unit of increase in foreign investments in time $t$ increases the average employment growth rate in the countries in transition by $0.02 \%(\mathrm{p}=.000)$ per year.

Table 4 - Modelling of average net wages percentage rate changes

\begin{tabular}{|c|c|c|c|c|c|c|c|}
\hline \multicolumn{8}{|c|}{ Estimates of Fixed Effectsa } \\
\hline \multirow[b]{2}{*}{ Parameter } & \multirow[b]{2}{*}{ Estimate } & \multirow[b]{2}{*}{ Std. Error } & \multirow[b]{2}{*}{$\mathrm{df}$} & \multirow[b]{2}{*}{$\mathrm{t}$} & \multirow[b]{2}{*}{ Sig. } & \multicolumn{2}{|c|}{ 95\% Confidence Interval } \\
\hline & & & & & & Lower Bound & Upper Bound \\
\hline Intercept & .010167 & .003279 & 10.267 & 3.101 & .011 & .002887 & .017446 \\
\hline [dev_st $=0]$ & .004574 & .003845 & 18.774 & 1.190 & .249 & -.003480 & .012627 \\
\hline [dev_st=1] & $\mathrm{ob}$ & 0 & & & & & \\
\hline$\Delta$ IFDI & .011896 & .009812 & 6.113 & 1.212 & .270 & -.012006 & .035797 \\
\hline$\Delta$ IFDI_lag1 & .002940 & .002064 & 4.915 & 1.424 & .215 & -.002393 & .008273 \\
\hline$\Delta$ IFDI_lag2 & .000675 & .001147 & 7.751 & .589 & .573 & -.001985 & .003336 \\
\hline$\Delta$ IFDI_lag3 & .002015 & .000692 & 3.832 & 2.913 & .046 & $6.079346 \mathrm{E}-05$ & .003969 \\
\hline
\end{tabular}

a. Dependent Variable: $\triangle \mathrm{ANW}$.

b. This parameter is set to zero because it is redundant.

Source: Author's calculation

Table 4 represents an increase in $\triangle \mathrm{ANW}$ due to $\triangle$ IFDI_lag3 in the observed period. In the countries in transition the amount is a $0.0046 \%$ increase, while in developed countries the increase in $\triangle \mathrm{ANW}$ due to the changes in $\triangle I F D I$ is almost null. This means that there is $0.0046 \%$ greater growth rate in $\triangle \mathrm{ANW}$ in the countries in transition, which justifies the logic explained in the previous model. The impact of the changes in $\triangle \mathrm{IFDI}$ on $\triangle \mathrm{ANW}$ is positive and statistically significant after three years of its performance. The model suggests that the greater the foreign investment, the faster the growth in ANW. If foreign investments double in time $t$ in country $i$, after three years the average growth rate of $\triangle \mathrm{ANW}$ will be $0.002 \%(\mathrm{p}=.046)$.

Both models include the developmental stage effects. The findings suggest that the effect of DEV_ST of the countries is positive and statistically significant $(p=.000)$ for the $\triangle E M P L$. In both cases, there is a positive growth rate in all the countries, meaning that $\mathrm{H} 0$ is rejected.

\section{DISCUSSION AND CONCLUSION}

This research empirically estimated the impact of the changes in FDI inflow on the changes in the employment rate and in average net wages in the ex-Yugoslav countries, using linear mixed-effects models. The analysis shows the existence of a positive but still very low impact of FDI inflow on both the employment rate and average net wages, mainly after 3 years of FDI inflow performance. The analysis shows that the developmental stage of the country meters for positive changes in the employment rate but not for changes in average net wages.

FDI inflow showed a positive, even if very low, impact on the examined labour market indicators. Perhaps the four transition countries should look at Slovenia's economic strategies as well as thoroughly investigating the FDI inflow options before adopting it. Moreover, regional collaboration should be strengthened in order to stimulate foreign companies to invest and to communicate with the region. Finally, it is recommended to study how to attract investors that pay higher wages, which involves studying also the availability and skills of host country employees and any potential brain drain. Lastly, it is recommended to enhance the efficiency and competitiveness of the national economy along with the companies through the implementation of strategies in order to solve employment and wage problems.

The findings of this research, as regarding average net wagesaverage net wages, are consistent with Bhandari (2007) and Kurtovic et al. (2015), authors who applied OLS regression estimation instead of linear mixed models. 
As for the impact of FDI inflow on employment, Jude \& Silaghi (2016) would provide an effective comparison with this research if the authors had used FDI inflow instead of FDI stock, because both analyses claim the positive long-term effect on employment. The findings of this paper partially confirm the findings of Pajovic (2007) as well, while disagreeing with e.g. Peric (2019), presumably because of the larger sample used in this research.

The limitations of the research and recommendations are as follows. Since there is little empirical evidence of the impact of FDI inflow on labour market indicators in transition countries, this paper offers findings to stimulate further research. In the first place, it is recommended that more countries should be included in the model. In order to estimate the impact of FDI inflow in each individual country, one could conduct single regressions to estimate the supposed impact of FDI inflow on the employment rate and on average net wages. That would serve to confirm or deny the hypothesis that for one country the effect of FDI inflow comes sooner because it is invested in the service sector, but in some others that are invested in industry or the production sector it comes later. The distinction is because there is reason to believe that the effect of FDI inflow is not equal for all six countries.

\section{AKNOWLEDGEMENTS}

I would like to express my deep gratitude to Professor Nemanja Stanišić for his helpeful suggestions for this research.

\section{REFERENCES}

1. Anderson, C. J. (2013). Longitudinal Data Analysis via Linear Mixed Model. Department of Educational Psychology, University of Illinois, Urbana Champaign. USA. Unpublished.

2. Bhandari, B. (2007). Effect of Inward Foreign Direct Investment on Income Inequality in Transition Countries. Journal of Economic Integration, 22(4), 888-928.

3. Bitzenis, A., \& Marangos, J. (2007). Globalization and the Integration-Assisted Transition in Central and Eastern European Economies. Journal of Economic Issues, 41(2), 427-434. doi: 10.1080/00213624.2007.11507030

4. Chandler, D. (2007). From Dayton to Europe. International Peacekeeping, 12(3), 336-349. doi: 10.1080/13533310500074077

5. Dabla-Norris, E., Honda, J., Lahreche, A., \& Verdier, G. (2010). FDI Flows to Low-Income Countries: Global Drivers and Growth Implications. IMF Working Paper WP/10/132.

6. Driffield, N., Girma, S., Henry, M., \& Taylor, K. (2010). Wage inequality, linkages and FDI. IZA Discussion Paper No. 4722. http://hdl.handle.net/10419/35998

7. Figini, P., \& Gorg, H. (2006). Does foreign direct investment affect wage inequality? An empirical investigation. IZA Discussion Paper No. 2336. http://ftp.iza.org/dp2336.pdf

8. Gopinath, M., \& Chen, W. (2003). Foreign direct in- vestment and wages: a cross-country analysis. Journal of International Trade \& Economic Development, 12(3), 285-309. doi: 10.1080/0963819032000132067

9. Grahovac, D., \& Softić, S. (2017). Impact of the FDI on Unemployment rate in countries of West Balkan. Review of innovation and competitiveness, 3(2), 65-82.

10. Hadžić, M., \& Pavlović, P. (2011). How to Overcome (SME) Crisis: Serbian Case. Acta Polytechnica Hungarica, 8(1), 61-80.

11. Halmos, K. (2011). The Effect of FDI, Exports and GDP on Income Inequality in 15 Eastern European Countries. Acta Polytechnica Hungarica, 8(1), 123-136.

12. Heck, H. R., Thomas L. S., and Tabata, N. L. (2014). Multilevel and Longitudinal Modeling with IBM SPSS. Routledge, New York and London.

13. Jude, C., \& Silaghi, I. P. M. (2016). Employment effects of foreign direct investment: New evidence from Central and Eastern European countries. International Economics, 145, 32-49.

14. Kurtović, S., Talović, S., \& Dacić, L. (2015). Panel cointegration analysis of Foreign Direct Investments and Average Net Wages: The case of four Western Balkan Countries. G. \& L. E. R. 19(1), 1-36.

15. Pajović, D. (2007). Foreign Direct Investments in Slovenia. Attracting FDI and Optimizing the Effects (Master's Thesis). School of Economics and Management, Lind University.

16. Perić, M. (2016). Brazilian economy in the XXI century: Economic performance from the Second Republic to nowadays. Saarbrucken: EAI.

17. Perić, M. (2019). Impact of FDI inflow on employment and average wage in Serbia. Management: Journal of Sustainable Business and Management Solutions in Emerging Economies, forthcoming. doi: 10.7595/management.fon.2019.0007

18. Šabić, D., Vujadinović, S., Milinčić, M., Golić, R., Stojković, S., Joksimović, M., Filipović, D., \& Sećerov, V. (2012). The Impact of FDI on the Transitional Economy in Serbia - Changes and Challenges. Acta Polytechnica Hungarica, 9(3), 65-84.

19. Stanišić, N. (2008). Do Foreign Direct Investments increase the economic growth of Southeastern European Transition Economies South-Eastern Europe Journal of Economics, 42(1), 29-38.

20. Taylor, K., \& Driffield, N. (2005). Wage Inequality and the Role of Multinationals: Evidence from UK Panel Data. Labour Economics, 12(2), 223-49. doi: 10.1016/j.labeco.2003.11.003

21. UN (United Nations). (2018). World Economic Situation and Prospects. Country classification, 139-179. New York: UN. https:/www.un.org/development/desa/dpad/wp-content/ uploads/sites/45/publication/WESP2018_Full_Web.pdf

22. UNCTAD. (2018). World Investment Report: Investment and new industrial polices. New York and Geneva: UN.

23. Zdravković, A., \& Martinović, B. A. (2016). To which extent did the FDI contribute to employment growth in transition countries? Paper presented at the International Scientific Conference: Impact of Economic Policies on Attaining Resilient Growth, October 27th, Belgrade. https://www.ien.bg.ac.rs/ies-conference/archive16.html

24. Zulfiu, M. A. (2014). Simulation Analysis of the Effects of Increased Foreign Ownership on Wage. Academicus International Scientific Journal, 9, 140-158. doi: 10.7336/ academicus.2014.09.10 